\title{
5
}

\section{Multilingual market cries}

Vuò sape e che parte so?

Songo e Napule e sto cca.

Sto vestuto a tripulino

P'o servizio ch'aggi'a fa.

Mmiez'a ll'Arabe, all'Ebreie

Rappresento o rinnegato;
Do you wanna know where I'm from?

I'm from Napoli and I'm here:

Dressed up like a Tripolitan

For a job I'm on.

Amongst the Arabs and the Jews

I am considered a traitor [to my own people];

Ma i mme guardo e fatto mieie, But I mind my own business,

Senza maie fa' suspetta.

Na parola contro a nnuie:

Puh, nu schiaffo, t'o sturdisco.

Chillo guarda, io nun capisco,

E illo dico, vuò cumpra?
Without letting people know [where I'm from].

If they say a word against us

[Christians/Italians];

I punch them and dull their senses.

They look at me, I don't understand, And I ask them wanna buy?

Extract from 'OO tripulino napulitano' ('The Neapolitan in Tripoli') by Raffaele Viviani (1925; translated from Neapolitan by the author)

Ci trovi nelle piazze, ci trovi nelle You find us in the squares, you find vie, ci trovi nelle strade, us on the streets, you find us on the roads,

Ci trovi pure al mare, camminare You even find us at the beach, walking per ore, con la voglia di fare. for hours, wanting to work hard.

Chiamami Vu' Cumpra.

Call me 'Wanna Buy'. 
Vita ambulante (cosa vuò accattà?), A hawker's life (what you wanna buy?),

Dalle borse alle sciarpe (nun ti From bags to scarfs (no worries), preoccupà),

Dai vestiti alle scarpe (nelle From clothes to shoes (in bulk). quantità).

Extract from 'Vu' Cumprà' by Goraman feat. ESA (2009; translated from Italian by the author)

$\mathrm{T}$ He extracts from the two songs reproduced here are both about the fraught experience of being a migrant street vendor. The protagonist of " $O$ tripulino napulitano' (Viviani 1925) is a Neapolitan hawker in Tripoli, Libya, in the early twentieth century, whereas the protagonist of the song 'Vu' cumprà' is a migrant Senegalese street vendor in contemporary Italy. At different moments in time, and in different contexts, they describe the tacit accords and identifications that migrant street vendors need to make with the settled population in order to be accepted and make a living. The Neapolitan vendor in Tripoli describes his attempts to blend in amongst local Arabs and Jews. The song reads like a confession of his true identity with the vendor's announcement that he is considered a traitor - to his own people, to his race, to his Christian faith - when discovered to be a Neapolitan man pretending to be a Libyan street vendor. Studies of Italian migration to the 'new world' (Harney 1998; Stella 2003) have spoken of the discrimination faced by Italian migrants there and explain the need for dissimulation expressed in the song. The vendor describes reacting rigorously and violently to insults in such a way that the aggressor's attention was turned away from his treacherous foreignness in order to re-engage a process of barter. The final phrase 'vuò cumprà?' is neither Italian nor Neapolitan (the vendor's native language, in which the song is composed) but, rather, a Neapolitanised distortion of Italian that has occurred because the vendor is speaking a language that is not his own. It is not clear whether the vendor experiences his Neapolitanness as something particularly stigmatising although we know that Neapolitans were particularly stigmatised both in the historic accounts of travellers to Italy and in descriptions of Italians abroad. Here it appears that the Neapolitan vendor makes his claim for the right to live and work in Tripoli on the basis of both his national identity and his ability to integrate into the local culture.

The various ways in which the Neapolitan vendor seeks to defend himself and practise his profession mirror those described by Goraman in 'Vu' Cumprà 
(Goraman, feat. Esa 2009), the second song that begins this chapter. In the mid1980 s the term $v u$ ' cumprà emerged as a derogatory term to describe the large numbers of migrants from West Africa who started arriving in Italy and took up work as street vendors (Faloppa 2011). It literally mimics the phrase that African vendors called out to potential customers in this period, meaning 'Do you want to buy?" Here Goraman describes black street vendors being racially insulted, whilst also subtly reclaiming the term as a source of self worth by associating it with the desire to work hard and hustle. ${ }^{2}$ By placing the two songs together we can see that the idea of the $v u^{\prime}$ cumprà is exclusionary - it places the street vendor as an outsider - whilst at the same time generating unsettling commonalities between the Senegalese street vendor and the history of Neapolitan alterity, precariousness and movement that the song 'O tripulino napulitano' captures. The key to understanding the negotiation of this status is through the linguistic choices made. Although Goraman is a Senegalese singer-songwriter based in the north of Italy, he uses Neapolitan when mimicking the calls of the Senegalese vendors - 'cosa vuò accattà?' ('what you wanna buy?') and 'nun ti preoccupà' ('no worries'). This highlights the fact that Napoli was an important entry point for Senegalese (and other) migrants when they started migrating to Italy, and the place where they often cut their teeth linguistically as street vendors in Italy (Riccio 1999, 2001). Their use of regional languages and styles was not an attempt at racial or religious dissimulation but was intended to engage potential customers in barter marking a moment where language became a site for transcultural connection, integration and claims-making about the right to belong and make a living in the city.

In both pieces the point of focus is the market cry, or the way in which the street vendors reached out across racial, linguistic and cultural boundaries to interpellate the potential customer. In this chapter I explore the examples of transcultural and multilingual speech performance related to buying and selling that took place in my fieldwork. I first examine greetings and bartering in Neapolitan, and their importance for migrant street vendors seeking inclusion and acceptance on the city's streets. I then turn to the frustrating process of bartering in English for Neapolitan street vendors at Poggioreale market. In Napoli, markets cries functioned as a humorous and multilingual speech genre that showed how alterity was handled by both settled Neapolitan and migrant vendors in order to facilitate trade and economic activity. This connected Napoli to other global port cities that had become sites of a 'practical cosmopolitanism born of an acceptance of - and indifference to - difference'. In Napoli, a pragmatic approach to living with difference involved the development of particular forms of 'cultural dexterity' and learning how to negotiate and barter in many 
different languages (Trotter 2008a, b). This hybrid, multilingual transcultural relationship was the result of the hard work involved in building new economic opportunities in a context of migration and precariousness (Hall 2009: 55-56; 2012; 2015). It also connected the past to the present when the raucous and comic 'Billingsgate speech' (Bakhtin 1984 [1965]: 7) revived the echoes of older market traditions of barter and haggling whilst adapting to the new urban reality.

However, given the increasing political and public pressure to close down and limit the amount of street vending in Napoli during my time there in 2012, the tactical deployment of these market cries also revealed how street vendors sought to legitimise their presence and continue making a living in a context where their livelihoods were threatened. Like other urban survival skills, street vending could be described as a type of hustling because it was often quite informal and was an earning tactic practised by communities stigmatised on the grounds of class, race and legal status. The tactical deployment of market cries, to facilitate trade and maintain good relationships with other people using the spaces around which street markets were set up, also revealed the defensive formation of a consciousness about the stigmatised nature of the profession (Hall et al. 1978: 351-391). Given that skill as a talker was key to the economic success of the street hustler (Bourgois and Schonberg 2009: 8; Wacquant 1998), the attention this chapter pays to market cries - the talk of the hustle - allows an examination of the oppositional class-consciousness through which negative ideas about street vending and street vendors were resisted and renegotiated on the ground.

\section{Greetings}

It was a sunny afternoon in late February and it finally seemed as though the unusually cold and lengthy winter we had experienced was releasing its grasp on the city. I was sitting at Comfort's clothes stall, at the Piazza Garibaldi end of Via Bologna market, warming my bones, chatting with Comfort and her cohort of Nigerian girlfriends, and generally watching the world go by. At one point, a Neapolitan street vendor joined the line of Guinean men selling contraband sunglasses from unregulated mobile market stalls at the entrance to the market. He was wheeling a huge, steaming, steel cooking-pot that he slipped into line with the rest of the men. Inside the pot was something that, although the seasons didn't mean anything any more, made those in attendance think greedily of summer: boiled corn on the cob. The man tilted back his head, took a deep breath, and cried out 'roi roi! roi roi!' starting out high and bringing the pitch of his voice down dramatically on the second 'roi' of each pair. A West African 
man, sitting on the railings at the top of the market, was particularly tickled by the performance and imitated the sounds the vendor was making - 'ahhhh-ohhhhh! Ahhh-ohhhhh!' - whilst laughing uproariously. The vendor looked sideways at his mocker with an expression of deeply insulted dignity but then turned back and carried on calling out to potential customers.

The corn vendor obviously knew a good thing because his stall was almost immediately besieged by stall-holders, market regulars and other passers-by. Together they chomped with satisfaction on their cobs and then joyfully tossed the husks over the blue wall that had been erected around the Piazza Garibaldi building site. Although anomalous next to the Guinean vendors, the Neapolitan man was easily incorporated into the line-up. An hour or so later a patrol of municipal police slowly started to descend down our side of the Piazza to clear out the unlicensed hawkers. As was typical, warning of their advance reached the men, via a network of people stationed up the side of the road, in time for them to wheel their stalls down Via Bologna into the backstreets of the Vasto neighbourhood and escape detection. The corn vendor was attentive to the same warning signs as the other men running irregular stalls near Via Bologna market and employed their same tactics of evasion, fleeing and then returning with them five minutes later to set up his pitch again.

Street vendors often called out humorously to potential customers as they passed through the market in order to persuade them to come and look at their wares. These greetings were ancient - relying on local conventions to describe the wares on offer and how much they cost - whilst nevertheless changing with the times. Although we all quickly understood what goods the corn vendor was advertising, many people, including me, didn't understand the meaning of his words. Gennaro later explained to me that he was shouting, in Neapolitan, 'Two lira! Two lira!', just like the street pedlars of the early twentieth century who sold portions of spaghetti in the street for that amount of money. The cobs actually cost 50 cents.

So the corn vendor's cry of 'roi! roi!' evoked the traditional figure of the Neapolitan pedlar. But this image was then interrupted by the interactive and comedic reception his presence activated amongst the people present, and the harmonious way he worked alongside the non-Neapolitan vendors. This revealed the innovative forms of transcultural economic collaboration through which different vendors made use of and shared the space of the pavement for their earning activities. This pragmatic approach temporarily did away with paranoias about political austerity and anti-immigration sentiment in order to ensure collective survival. But it also hinted at a kind of oppositional consciousness to established hierarchies. The success of the vendors' intersubjective 
communicative tactics depended upon a place-making struggle being enacted that produced the space of the market according to the needs of the people making a living there. The cry and response of 'roi! roi!' tactically produced localised spaces of manoeuvre in situations of inequality and domination through the use made of it by the vendor and its reappropriation by passers-by, shedding light on the reciprocal and transcultural politics of street vending.

These intersubjective politics could be deeply ambivalent and depended on regular reiteration. When I met him, Modou had been laying down his piece of cloth on the same patch for the last seven years. He was a Senegalese street vendor who sold high-quality, fake designer accessories that were crafted in factories in the city. As such, his legal status and place on the pavement were particularly precarious. Repeated arrests and seizures of his merchandise had made it impossible for him to gain a work visa. He had developed relationships with a lot of the people who lived and worked in the area, in particular the men who worked in the bar he patronised nearby, and a couple of men with whom he enjoyed lively football banter. One person even allowed him to store some of his merchandise in his shop to avoid him having to carry it back and forth. Modou was careful to greet everyone he knew as they passed by in an eclectic mix of the local and international forms of salutation he had picked up on the job. Doing participant observation with him was often a series of:

Modou: Uè Lellooo! [Yo, Lellooo.]

Lello: Tutt'a post uaglio? [All right, mate?]

Modou: Hola!

$\mathrm{X}: \underline{\text { Myfren! }}$

Y: Modou!

Modou: Cava?!

Modou: [to one person] What's up, hey! What the hell do you want? Get the hell out of here!! [to another person] Hola Chico!

These highly raucous and vociferous greetings were an important way in which Modou established reciprocal relationships with the Italians who were his occasional customers and whom he came into contact with everyday. They didn't question his right to set up in that spot and, beyond patronising his stall, often helped him in some important way. This shouldn't be taken to indicate genuine affection and trust between Modou and the people he greeted so warmly. I remember that, on one occasion, following an onslaught of greetings, he turned to me and said, 'I just can't stand those Italians.' His throwaway comment 
revealed how exhausting these performances of lightly humorous transcultural greeting were for him.

Occasionally, though they were unplanned, discourses about cultural difference and solidarity were also opened up in these market greetings. For example:

\section{Modou: [to Italian man walking past stall] Merry Christmas!}

Man: What?! But you don't celebrate. You're Muslim!

Modou: [holding both palms up] What's that mean? I can still give you season's greetings!

Man: You're right: one race. [He makes a fist on his chest in solidarity before hurrying off.]

Not all migrant street vendors shared Modou's self-confident and jokey linguistic style. Ibra, another Senegalese vendor I worked with, preferred simply to greet people he knew with 'Ciao', or call out 'Prego' or 'Prego capo' ('tell me' or 'tell me, Boss') when potential customers lingered by his stall. These forms of greeting were more deferential and devoid of humorous intent, partly because Ibra was a much quieter and shyer person. Also, his greetings were the traditional ones that were utilised by market vendors in Napoli. It was significant that Ibra did not choose jokey Neapolitan forms of greeting, as Modou did, even though he certainly understood Neapolitan and would have known how to say things like 'Uagliò! Tutt'a post'?! ('Hey man! What's good?!') if he wished to do so. The people I was working with were individuals who found ways of coping with their situation in the manner best suited to their personalities. As a devout Muslim, Ibra took seriously the lengthy religious and cultural formalities that structured Wolof greetings. The friendship between him and Giovanni, who owned the grocery shop behind his stall, was genuine and respectful and, as Giovanni told me, took some time to develop. Every time I came to work with Ibra we would greet each other, always enquiring after each other's families, and then he would remind me to go and greet Giovanni before I started any fieldwork with him. His way of calling out to people also seemed to me to be a signal of the precarious nature of his spot on a city street that was regularly being patrolled by police at the time. Aside from his friendships with Giovanni and with Salvatore, there were predominantly tense relations between the street vendors and shop owners along the road. Ibra's more cautious choice of greetings appeared to be in recognition of these fraught local dynamics. His and Modou's different styles of greeting reflected the particular conditions of communication and attendant power dynamics in their respective market spots. 
However, the use of humour was frequently important in street vendors' attempts to call out to potential customers. In particular it acted as a buttress for communicative difficulties. On one occasion, at the start of summer, I was sitting at a market stall set up next to the main railway station. A group of Ivorian men and women were standing in front of me chatting in French about how they were going to organise their day. One of the men said to the group, in French, 'Please could you drop my brother off at home', and started to move away from his companions. The rest of the group also started walking but were then stopped in their tracks by a Neapolitan man on a moped who rode up onto the pavement and screeched to a halt in front of them. They stopped talking and stared at him with wary curiosity. He held up one index finger to them, raising his eyebrows to indicate for them to wait a minute and pay him attention. Then, wiggling his eyebrows up and down in clownlike amazement, he reached down for a plastic bag held between his legs and drew out some ties. Again he raised an index finger and told them 'one euro!' in English. He sifted through the ties and spread them out in his hands to show them off better, all the time looking at the ties in wonder and looking up at the group with an amazed smile and raised eyebrows. Everyone smiled at the man and one of the women did crane her neck to have a better look at the ties. The Ivorian man who spoke before turned back to find his group still fixed on the spot. He approached the Neapolitan man, rolling his eyes: 'Look, one euro!' said the vendor. The Ivorian man waved his hand dismissively saying 'Leave it out', in dialect, and started shepherding the group away. The vendor protested, in English and then Italian, 'one euro! Look! The woman was interested!' They moved on and the man shrugged his shoulders dramatically, shaking his head in bewildered amazement that they could miss such a good deal. Then he started the motor of his moped and drove off.

The Neapolitan man in this scene did not have a fixed stall but sought to sell his wares by roaming the city, itinerantly, on his moped. Mopeds were a cheap mode of transport in Napoli and whole families were known to make use of them to travel around the city. This particularly humble form of vending allowed those who practised it to make good use of busier parts of the city at different points in the day and week. On the switch-side it wasn't possible to carry large amounts of merchandise and they lacked the security and familiarity offered by a regular stall and customers. Here the vendor used his moped as a prop to grab the attention of the people he wished to offer his ties to. This was dramatic and funny, as well as being slightly threatening - people did often drive their mopeds along the pavement in Napoli and pedestrians were advised to be wary of them lest they try to grab a handbag as they pass by. However, the vendor deflated any anxiety he might have created with a comedic performance that combined gesture and the 
small amount of English he was able to use. Whether or not they spoke English, there was no doubt about the meaning of 'one euro', when it was combined with his hand gestures and facial expression.

His comedic performance was based on the assumption that the group of Ivorians would be familiar with local masculine stereotypes such as that of Pulcinella in the city's commedia dell'arte tradition. His choice to use English to grab their attention revealed the way in which English has become a lingua franca amongst people who have been subjected, in uneven ways, to Anglo-American economic and cultural hegemony. These things signalled the complexity of meanings about race, difference and belonging in the Neapolitan context. But they also spoke to the significance of choice regarding how to live with difference in everyday life, where intersubjective connections can be made without attendant power struggles and without a need for full transparency in communication.

\section{Bartering in Neapolitan}

One evening, as I was standing with Modou next to his cloth spread out with designer bags, a young couple walked past us, taking an early evening stroll. They were fashionable; both of them wore skinny jeans and branded trainers. The young woman stopped at Modou's stall and picked up a Louis Vuitton tote that she liked the look of. They discussed the merits of the item in Neapolitan and then the woman turned to Modou.

Young woman: How much do you want for this?

\section{Modou: Forty euros}

Young man: [holding up a smaller version of the same bag] Myfren, how much for this 'Uitton?

Modou: Thirty-five.

Young man: Come on that's too much! Listen here: I work in the factory where they make these bags. I know how much they cost. How much d'you pay for each one there: twenty?

He puffed his chest out and grinned at his girlfriend, who giggled, rolling her eyes and smiling at me.

Young woman: Don't worry about it!

Young man: Twenty-five, myfren, twenty-five.

Modou: $O K !$ 
The young man paid Modou, who went to get the protective cloth sack that came with the bag.

\section{Young man: Don't bother. She's gonna wear it right now.}

The couple walked off smiling and holding hands. Modou commented to me that he had achieved quite a good price considering what he could usually get selling similar items on the street in Napoli. He added that he had paid $€ 17$ for the bag at the factory. Clearly his profit margin remained healthy even if he had seemed so agreeable in lowering the price to meet the young man's offer.

In this exchange the young man tried to show off his insider knowledge of the contraband industry in Napoli to secure a profitable deal. Whether or not he actually did work in the factory, making fake bags as he claimed, he made use of rumours that circulated in certain quarters of the city about the health and value of the market. Their choice to conduct the whole negotiation in Neapolitan was significant. Both the young man's and Modou's use of Neapolitan suggested a shared insider knowledge about the contraband industry in the city. This reflected the unstable and codependent politics of a local business that implicated migrants and Neapolitans at different stages of manufacturing and sale; although, of course, West African street vendors took the biggest risks and paid the highest price for carrying out this illicit trade. Using Neapolitan in street markets was a sign of an edgy, complex and ambiguous transcultural codependency in Napoli.

The use of Neapolitan evoked local performance of streetwise know-how that guaranteed respect was forthcoming on both sides. Because of the history of political, economic, cultural and linguistic subordination in Napoli, and because of the kinds of oppositional style that have emerged in an urban scenario where organised criminality competes so openly with the State for control of the local economy, Neapolitan use has come to stand for a particular sort of gangster, or guappo, street machismo. It was used by men - as well as women playing u'maschiolona - in playful and competitive situations that took place between Neapolitans and migrants in racialised transcultural interactions, to avoid losing face and to give out a tough vibe that assured respect and survival. The young man spoke loudly and ostentatiously, and called Modou 'myfren', a cheeky and slightly underhand way Neapolitans have of addressing African men. If he had wanted to be more respectful he would have said, 'amico mio', in Italian, not English. Modou was not Neapolitan but had learnt to transact in this way following long experience and residency in the city. The confidence he displayed came from the recognition that he took big risks selling luxury fakes such as these. 
He asked for high prices because he knew people would stick around to haggle him down. He was also able to respond quite brusquely in dialect reflecting the fact that street markets were particular spaces in which migrant men are able to use Neapolitan in joking and disrespectful ways that were not permitted to other migrants in different working environments.

The decision to barter in Neapolitan reflected the specific dynamics within the local informal economy, as well as gendered and racialised tensions that played out in particular ways in street markets in the city. Humour was also central to market exchanges conducted in Neapolitan. The laughter produced was unofficial and informal, and its very distinction from the verbal forms used in official public discourse allowed new kinds of temporary and ambivalent hierarchies to emerge.

Modou: [to young man carrying a sports bag] Whats'up?

Man: All good, all good.

Modou: Where you going?

Man: To the gym.

Modou: $A h$.

Meanwhile, an older man snuck up to Modou's stall while he was talking to the younger man and picked up a bag, pretending to run off with it.

Modou: [noticing] Hey, thief! Marioooo!

[Modou laughed and jogged over to the old man to retrieve his bag.]

Modou: [turning back to the young man] You're not watching the match tonight?

Man: No-I'm going to the gym.

Modou: You don't like football?

Man: [bending to pick up a bag] This is nice.

Modou: There's another one even more nice nice ... you want it? 180 euros. You want it or not?!

Man: You wanna give it to me for free?

Modou: If you want!

Man: Wow, good present!

Modou: Where you gonna have the party then - here or at yours?

Man: See you later!

The joking sociality of Modou and the Neapolitan man's banter about football, the gym and the bag he liked was sidelined by the older Neapolitan man playfully 
attempting to steal Modou's merchandise. The older man was not actually stealing the bag. Like the moped-riding tie vendor in the previous section, he was playing up to the stereotype of the Neapolitan thief. Modou responded by participating in the jokey role-play and calling him a 'latr' (from the word latrina, or 'bog') in Neapolitan and laughing. As Sarnelli noted in his work on markets in Napoli, this was a common practical joke carried out by Neapolitan men against Senegalese vendors that had undertones of bullying to it (2003:30-31). Here Modou laughed it off and called the man out - again in Neapolitan - so as to show he knew what was going on and that the older man couldn't get the upper hand over him. Nonetheless, he had to run over to retrieve his bag from the old man and not vice versa. The gendered balancing of power between Modou and the older man was echoed in the heteronormative, 'blokey' conversation Modou was also simultaneously having with the younger man about football and parties. Neapolitans often jokingly asked for items to be given to them when they haggled at market stalls. For example, I heard this exchange taking place at Poggioreale market.

Neapolitan woman: I've got to give someone a gift!

Ciro: Yes it's YOU that's got to give the gift to someone, NOT me!

Neapolitan woman: [laughing] That's a good one: 'you've got to give the gift' ....' Ciro: You know my love, I would like to do it but I've got no dough!

Even though the man at Modou's stall didn't have any real intention of buying the bag he picked up, the performance of bartering in Neapolitan allowed for delicate socialities and balances of power to be explored by the two men. The exchange ended with Modou agreeing to see him later for a party. The enjoyment taken from their performance of Neapolitan bartering presented the possibility of transcultural socialities being extended from a cloth on the pavement into the private sphere of the home.

\section{Bartering in English}

The status of English use in street markets was somewhat different and offered an important insight into the ways in which Neapolitan street vendors had adapted to cultural difference and global economic changes since more migrants started to arrive in the 1980s. Over the years, market traders in Napoli had learnt to barter in a number of languages that they had picked up through their work and would not need, or necessarily be able, to use outside the context of the street market. As I described earlier in the book, Gennaro related a situation to me 
around the Ferrovia where phrases and lexical items from Arabic, English, French and Ukrainian had been very useful to the Neapolitan traders when migrants first started arriving in large numbers, but where, now, different variations of the local market patois of Italianised Neapolitan or Neapolitanised Italian were mostly sufficient for the conduct of trade, alongside the occasional bits of English and French. This was what I noticed happening too. However, given the particular composition of the buyers going to Poggioreale market, where people flew in from Europe and West Africa specifically to buy items for shops before taking them back home, the Italian vendors there had to be able, in Alessandro's words, to 'barter in all the necessary languages'. A lot of money was exchanging hands in some of these transactions and they were often a reasonably lengthy process. English was the dominant language of barter with foreign customers, and the imperative of getting by in situations of linguistic insecurity could generate stress and paranoia.

My records of multilingual barter at Poggioreale show the considerable communicative skill and edgy zeal that were involved in using English to barter. This zeal coexisted alongside paranoia, resentment, and frustration about economic securities and the problems of communication. For example, one sunny day in late March I was at Poggioreale market, which was starting to pick up after an unusually slow winter. Customers thronged around Eddy Pell's fabric-covered tables and elegant displays of accessories, picking things up and examining them inside and out. I could hear vendors calling out in Neapolitan to customers across the market: 'come look, come look!', 'one eurooooo!', 'eighteen for three euroooo!' A West African woman with a male companion and a small child in a buggy approached the stall and started to examine some handbags. Recognising the possibility of a sale, Ciro approached her.

\section{Woman: [holding up a small brown leather handbag] This how much?}

Ciro: Thirty.

Woman: Give me twenty-five. I buy four.

Ciro: Is not possible. This is not Chinese. This is all Made in Italy - excellent quality!

Woman: Please, please!

They continued to negotiate prices, with Ciro explaining that he generally only gave a discount on larger purchases. He relented and the woman bought five bags at $€ 25$ a bag. She and her partner started to pack the purchases in a large holdall they had brought with them. The woman's child was leaning out of the buggy, touching the handbags and pulling on the scarfs which were artfully 
draped round their handles. It was making Ciro nervous that his products would fall and get damaged, so, to attract the woman's attention to this, he said 'Your daughter is like my daughter - always touching!' The woman smiled distractedly and, pulling her child's hands away, said goodbye and moved off.

This exchange showed the levels of linguistic complexity that traders at Poggioreale - who had generally not studied much English or spent any time in an English-speaking country - needed to be able to manage when speaking to their customers. The tension that arose from conducting business in chaotic and crowded public spaces could be managed, depending on the linguistic resources at the disposal of the vendor or the customer. Ciro's basic English was good enough that he was able to communicate tactfully to his customer that she needed to stop her child making a mess of his products. The comparison he made about their daughters sought to establish a reciprocal link between his family and her family's wellbeing.

The language was functional and relied on long-established scripts that were used by vendors in street markets across the city when trying to convince their customers to part with money. Vendors explained that their products bore the 'Made in Italy' merchandise mark and so supposedly were handmade from leather by local craftspeople. This meant they were not cheaper imports from China, generally made from inferior material and mass-produced. They would tell them that, given that these products came directly from the warehouses in the city where they had been manufactured, they were already at the best possible price, but were not as cheap as Chinese merchandise because of the difference in quality.

This script was contextually situated within a widespread narrative in Napoli that Chinese competition in the retail market was destroying people's livelihoods. Since the 1990s, some areas of the city, and surrounding suburbs, had become enclaves of Chinese-owned warehouses and shops, where Chinese imports were sold in bulk directly to the customer. A lot of the resentment that people felt towards Chinese migrants and their economic activities in the city drew on ancient orientalist stereotypes about Chinese cultural insularity and more contemporary fears about Chinese economic expansion locally and globally. Many of my research participants told me that cheap Chinese imports had destroyed the market for 'Made in Italy' products in Napoli over the last decades. The Neapolitan and West African street vendors I spoke to told me they had totally changed what they sold and they claimed that Chinese stockists frequently undercut them when selling the same products. I often heard grumbles that the Chinese worked so hard that anyone else was unable to keep pace. I also heard much speculation that Chinese economic success was fed by the involvement of the Chinese mafia. This common assertion joined other, more fantastical, rumours that circulated about 
the Chinese in Napoli. For example, I was told about an urban legend that there had never been a Chinese funeral in the city. When someone died people said that their body was sent back in a container to China and their documents were recycled for another person, who entered using the dead person's visa. Thus, the Neapolitan neomelodic singer Pino D'Amato captured a number of imaginations in the city when he dedicated an entire album to the issue of Chinese economic activities in Napoli. The song 'Sti Cinis' (2007) starts with a deeply distasteful oriental riff, and then continues in the following way:

Sti cinis c'hann cumbinat?

Tutto Napule s'hann pigliat

Nun se ne tornan
What have these Chinese done?

They've taken the whole of Napoli

They'll never leave

D’Amato (2007; translated from Neapolitan by the author)

These racialised narratives about the Chinese elided the fact that much Italian manufacturing had moved out of the city to warehouses in regions such as Puglia, where rent was cheaper and there was more space for large vehicles to move around (Amato 2017: 25). In the majority of cases, particularly in the areas in and around Napoli, the Chinese had moved in to take spaces abandoned by Neapolitans. Their success in the region reflected more the logics of late capitalist consumption and globalisation than any sort of Chinese imperialist takeover.

My expertise in English made me popular with street vendors at Poggioreale. One of the first things they said to me when we agreed to work together was that I could help them speak to their English-speaking customers. The following two excerpts show how this worked in practice.

Peppe: Tell her it is all stock price.

Anton: Yes explain her ...

Me: He's saying that -

Peppe: Tell her it's already a great price.

Nigerian woman: Yeah I want him to give me a good price. I buy from him all the time. All the time here I come. I come here and I buy stuff. So he has to give customers discounts.

Me: [to Peppe] She says she comes here all the time so she wants a discount.

Peppe: It's already discounted. Already discounted!

Me: He says it's already discounted ... 
Nigerian woman: You know customers can't be satisfied like that. He has to do something. So you'll be happy and come again.

Me: [To the woman] Shall I say that?

Nigerian woman: Yeah.

Me: She says you have to satisfy your clients so they come back again.

Peppe: No, no no!

Nigerian woman: Why are you being like that?!

Peppe: [to me] Do you understand? Or can't you pick up anything?

Me: They're comparing things, like colour and material ... thinking about what would sell well.

Peppe: Oh!

Peppe: Sorry, what's your name again?

Me: Antonia.

Peppe: Tell them those bags cost loads of money -

Me: Yes and you bought them at stock price -

Peppe: For their benefit.

Me: OK so he's he's saying that this bag originally was very expensive but they buy it from the factory, create a stock and sell it at a lower price so the quality is very good and the price is very good.

Ade: So what is he saying actually?

Me: Sorry?

Ade: What's he saying?

Me: That's honestly what he's saying. Look: this is the original price ... because what they do is they buy - I can't remember what the word is - they buy ...

Ade: In quantity?

Me: Yeah. They buy in large quantity to give you a good price. You come to Poggioreale because everything has been bought directly from the factory so it's a good-quality bag at a good price.

Ade: $\underline{\mathrm{Ok}}$.

Peppe: Tell him that these ones are leather and are a real bargain - only forty euros!

I did as Peppe asked and then explained my project to Ade and his sister. They agreed to have their photos taken and the conversation recorded whilst they carried on haggling over the bags. Once they had selected the bags, with Alessandro and Peppe's help, the actual negotiations started. As Figure 12 shows, I remained in 


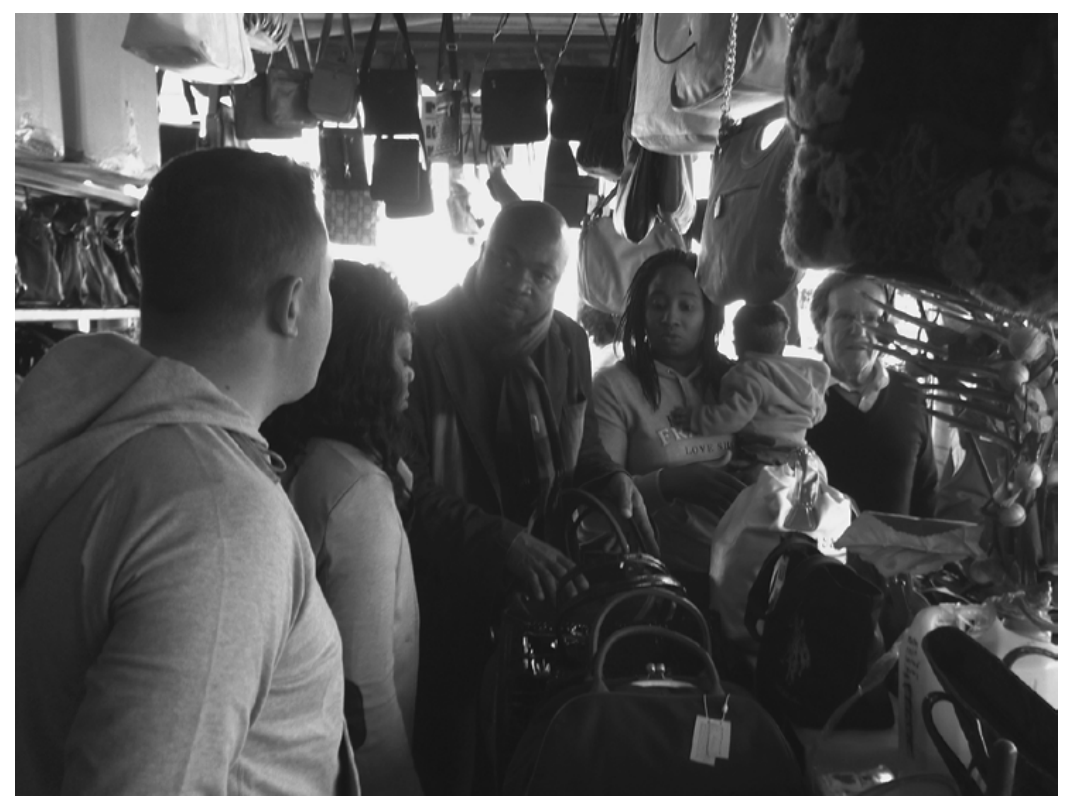

12 Haggling at Peppe's Bags

physical proximity to the discussion as I recorded and photographed it, so that I could continue assisting with interpreting.

Peppe: So ...

Ade: $\underline{\text { So ... we are buying plenty! }}$

Peppe: So look at this, look.

[He raises his eyebrows at me, nodding to Ade to indicate I should cut in to get Ade's attention.]

Me: You see this?

Peppe: This: forty, forty, forty, thirty and thirty. [indicating all the bags] One-hundred-and-eighty!

Ade: One, two three...

Me: Three at forty ...

Ade's sister: Check how many are forty! These two thirty thirty ... he can't give you good price?

Giuseppe: No. Finito! This is the best price!

Ade: No no no no: customer. Me: talk to me. I'm your customer.

Giuseppe: No, no: finito. If you want: one-hundred-and-eighty. One-hundredand-eighty. Finito. 
Ade: Customer, customer ...

Giuseppe: No, no ... One-hundred-and-eighty.

Ade looked at me in exasperation, indicating with a flick of his head that I should intervene on his behalf.

Me: I'm not a haggler.

Ade: Oh, you don't want me to haggle?

Me: Well you can try but I can't do it for you!

Peppe: This is already at stock price. Tell him it's stock price.

Me: He says it's already stock price. He can't ... at the risk of not making a profit. And he says that [to Peppe] being a client -

Ade and Peppe eventually agreed on the original price of $€ 180$. Ade paid in cash, with a $€ 500$ note. Peppe searched for the complementary mirrors that came with the bags, and Anton, their Ukrainian assistant, was instructed to remove the stuffing and pack them in cloth sacks.

Large amounts of money were being exchanged in these sorts of transaction, and tempers could fray quite quickly with each party accusing the other of being crafty or discourteous. The photo I took is also illustrative of the closeness of the space under the roofs of the stalls at the market, which obliged people to invade each other's personal space whilst haggling, leading to further anxiety and discomfort (see Figure 12). As the above episodes showed, when I was placed in the middle of bartering processes, both sides questioned me closely, unsure whose side I was on. I found myself in an awkward position, as I felt obliged to help out but was aware of the ways in which I was influencing the sale and, often, endorsing the point of view of the Neapolitan vendors who had called me into the process, by embellishing the things they were asking me to translate. What made things worse was that I clearly wasn't able to mediate the deep currents of transcultural tension and distrust that these processes of barter evoked, as could be seen from the raised voices and body language of both vendor and customer. Ade, who was new to the process of buying abroad, found the negotiation of cultural and linguistic differences in the market a major source of worry. He told me separately that not being able to communicate effectively with Italians was making him feel distrustful and isolated. The Neapolitan street vendors at Poggioreale were similarly anxious. As well as having to barter in foreign tongues they complained about the haggling style of the West African buyers, which they thought was overly aggressive. 
The importance of the African buyers at Poggioreale market complicated established racialised scripts and hierarchies about getting by and about economic cooperation in the city. Barter in English reawakened older inferiority complexes about speaking English which recalled melancholic memories of Italian emigration. This pricked at complexes about the supremacy of Anglo-American cultural, political and economic hegemony, and joined new paranoias about Chinese economic supremacy. Instead of seeking work from Italian employers - and obviously then contributing to the economy through tax and consumption - the predominantly West African buyers at Poggioreale created economic opportunities for Italians, in contrast with the dynamics of street markets in the rest of the city and in contrast with an anti-immigrant politics that said foreigners took jobs and resources from Italians.

Although the stalls at Poggioreale were owned by Italians, the vendors often decided to hire English-speaking West African assistants to help them communicate more effectively with their customers. Christopher was a Nigerian-Togolese man who had been hired by Peppe to help out on his stall in the market on busy weekend days. When we first met he showed me his light-blue UN passport, which indicated that he held recognised refugee status. He was a devout Christian who spoke little Italian and didn't tell me about his experiences of arriving in Italy beyond showing me this document. A lot of the time, I saw that the frustration and resentment Peppe and Alessandro felt about bartering in English were taken out on Christopher and Anton. On one occasion, during a rather stressful negotiation where Alessandro had punched a series of prices into the calculator incorrectly, and so ended up having to accept a lower price from the customer, he turned to Anton and shouted viciously, 'You've been here for six years. When are you going to learn some Italian?' Anton stared at him without speaking. On another occasion, Giuseppe instructed Christopher to remove the paper stuffing from the bags he had just sold and Christopher didn't do anything because he hadn't understood. 'Take out the paper! The paper!', screamed Peppe in Italian, miming his hand going inside a bag and grabbing something. Christopher responded, 'Oh the paper!', before muttering in English 'You should have just said.' Later on that same morning, two belt stands on the side of the stall fell over in the wind. Giuseppe shouted at Christopher to go and get a canister to weigh the bases of the stands down better whilst he and Anton set about picking up the belts. Christopher came back with some rope and Peppe screamed 'a canister!' at him, making the shape of a canister in the air. When everything was back in its place Giuseppe told me he regretted having lost his patience. He said that he was just really worried about the stands breaking as they were expensive. 
These excessive responses to misunderstanding and incomprehension were about power. The levels of precariousness both employees were situated within were incomparable to any anxieties Peppe and Alessandro might have about stands breaking or paper not being stuffed quickly enough into a bag. The aggression they frequently meted out to their foreign employees was emblematic of the kinds of lurking racist antipathy that manifested itself in performances of masculine dominance.

The Poggioreale vendors also made deals with West African taxi drivers who ferried customers and their goods between Poggioreale market and their hotels. These men also brought clients direct to particular stalls, in exchange for a small fee. Giuseppe only paid them if he had managed to sell his more costly leather items, as he said he couldn't afford to pay for customers who came and only bought Chinese goods. On one occasion a taxi driver approached the stall to ask for his cut. Peppe explained that the customer had only bought Chinese products so there was no payment. The man got angry and told him in threatening tones, 'OK, I'll give it to you for free.' Peppe looked intimidated and shrugged his shoulders, reaching for his pocket. Alessandro noticed this and shouted at the taxi driver to 'Fuck off and die!' The man scowled and strode away. Alessandro then accused his dad of being weak and needing to toughen up.

At Poggioreale market the imperatives of a trade that had to be conducted in English created cultural and linguistic interdependencies that rubbed uncomfortably alongside contemporary understandings about race, difference and belonging at the national and regional level. Barter in English could as much allow for the establishment of situations of multilingual cohabitation - even if they were fleeting moments - as it could precipitate a descent into misunderstanding and miscommunication, and so bolster established racial hierarchies. The tension surrounding the use of English in market haggling revealed a consciousness about the hierarchical and historical weight ascribed to English. This understanding about communication mapped onto a cultural understanding about power and hegemony and how it had brought people together in one place, through colonialism and interconnected processes of political and economic subjection.

\section{Multilingual know-how as an oppositional consciousness}

Multilingual economic transactions and haggling in Neapolitan street markets often appeared joyful and exuberant although, as I have noted, they could break down and descend into abuse. Street vendors talked about enjoying their work and taking pride in earning their money honestly and in a traditional way. As Ciro of 
Eddy Pell at Poggioreale told me, 'the market is an anti-depressant', even when business was slow and the weather was freezing cold. Gennaro explained that:

There are people in this city who don't want to suffer like we do. But we [market vendors] really like the contact you have with people in this job ... and being at ease with what we do. You know, you go home and you've worked honestly, you've met other people ... In summer we meet people from Germany ... Brazil ...

Their success in conducting business and making a living depended on multilingual dexterity and edgy know-how, or sapè fà. In his work about precariousness in Napoli, Italo Pardo described sapè fà as something shifting and fluid that drew on an understanding of geographical, political, economic, social, administrative, moral and cosmological boundaries in Napoli. Know-how was key to the successful negotiation and mediation of unequal and ambiguous power relationships in Napoli, particularly when one was engaging in practices that could blur the boundaries between the formal and the informal (Pardo 1996: 184, 136). In the street market sapè fà manifested in a particular form of fiery and persuasive selling spiel. It was a way of communicating that was multilingual and switched between a variety of linguistic codes in the effort to be persuasive and impressive. The following excerpt from a recording in the field shows the joy inherent in the market cry.

Gennaro: [to approaching client] Tell me, tell me!

Customer [West African man]: [pointing to a pair of socks] How much this?

Gennaro: This here is one size fits all.

Customer: [another pair of socks] And this?

Gennaro: This one is size 39.

Customer: 39 ... hmm ... And how much does it cost?

Gennaro: This pair costs three euros.

Customer: How much?!

Gennaro: Because this pair is better ... these others cost two euros. Can you see where I've put the price?

Customer: Too expensive!

Gennaro: Hmm ... but have you understood what kind of sock this really is?

Customer: I've understood!

Gennaro: No I want to show you. I'm not forcing you to buy, yeah? I just want to show you. Ok, so this kind of sock is a technological thing. Can you see 
those bands inside the edge that stop the sock from slipping off? The fabric is also of a kind of quality that really keeps the heat in! It's not a Chinese product but Italian-made - and that's an important fact. Look: 'Made in Italy', written on the packet.

Customer: Please, I can't speak Italian well!

Gennaro: Yes - I'd realised you weren't Italian! [laughs]

Customer: I have little money.

Gennaro: Trust me, I'm worse off than you, maybe you haven't understood!

Let's do two euros fifty, yeah? Come on, amico mio!

[The customer threw up his hands in refusal and walked away.]

Gennaro: Look here, there's about three kilos of wool in this sock. Three euros!

Gennaro started his spiel with 'Tell me, Tell me!' This opening cry, a rough translation of the Italian 'prego, prego!' was commonly heard shouted out to customers across Italian markets. Etymologically prego derives from the Latin noun precaria, meaning something that has been obtained through prayer (Etimo 2008). Needless to say, it is connected to the idea of precariousness, highlighting the links between market vending, market crisis and material survival in Napoli. Despite initial linguistic confusion - Gennaro thought his African customer was asking for information about sizes where in fact he was asking about prices - he nonetheless launched into a complicated technical explanation about the socks' manufacturing as a way of dazzling and impressing the man into buying. He took advantage of the fact that the man's Italian was not strong enough to be able to follow the entirety of his explanation and laughed knowingly when the man asked him to slow down. However, he switched his expert stance towards the end of the transaction. When the man explained he didn't have much money, Gennaro positioned himself as equally needy, appealing to the client's sympathy and generosity to make the sale and calling him 'amico mio' ('my friend').

Gennaro's market sapè fà also took advantage of a complex understanding of the different linguistic subjectivities animating public life around Piazza Garibaldi. Like many other transactions I observed, the discussion was fast and concluded quickly. Gennaro also became quite pushy in an attempt to complete the sale, something he admitted he didn't like doing but felt compelled to in the harsh economic climate. On this occasion he was unsuccessful. However, the diverse and aggressive selling tactics he used highlighted his relatively privileged position in the city's street markets. He was located in ways that relied on the security he enjoyed as a man and as an Italian citizen with particular rights and resources that migrants and female vendors didn't have the privilege of making 
use of. His approach was different from that of Modou selling fake designer bags, or of the Neapolitan street vendors struggling with English at Poggioreale market.

The horizontal dynamics of street vending in Napoli were coded and enacted through particular cultural languages that aimed to ease trade whilst also opening up the possibilities for other sorts of transcultural negotiation and solidarity. Neapolitan market cries had ancient origins, but there was now a new community of vendors who were creating a language of cultural communication in markets. If struggles over power can be understood by looking at the struggles going on within signification then the negotiation of market cries revealed both the external pressure that was affecting the livelihoods of vendors, and the different positionalities of people making money on the pavement. The deployment of market cries revealed the history of lumpen suffering and hustling that connected the Neapolitan and Senegalese hawker in the ambiguously unequal forms of transcultural collaboration that took place on the pavement, as well as in a shared history of economic marginalisation that had been mitigated by migration. Market cries revealed a will to survive and overcome a fate of precariousness and marginalisation.

\section{Notes}

1 The emergence of its use across the mass media was met with anti-racist pushback that prompted serious reflection on the problem of racism in Italy. The term is now widely acknowledged to be offensive and is not generally used. I didn't hear anyone use it in my research. Instead, people use the politically correct term venditore ambulante (street vendor) - which, nonetheless, is understood tacitly to mean a migrant and most probably black African street vendor.

2 This is typical of the playful verbal style of Hip Hop where previously discriminatory language is reappropriated, reclaimed, and so defused and disempowered (Bramwell 2015; Smitherman 2006: 118). 